\title{
Restoring forests: What constitutes success in the twenty-first century?
}

\author{
Douglass F. Jacobs ${ }^{1} \cdot$ Juan A. Oliet ${ }^{2} \cdot$ James Aronson $^{3,4}$ • \\ Andreas Bolte $^{5} \cdot$ James M. Bullock $^{6}$ - Pablo J. Donoso ${ }^{7}$ • \\ Simon M. Landhäusser ${ }^{8} \cdot$ Palle Madsen $^{9} \cdot$ Shaolin Peng $^{10}$. \\ José M. Rey-Benayas $^{11} \cdot$ John C. Weber ${ }^{12}$
}

Published online: 5 October 2015

(C) Springer Science+Business Media Dordrecht 2015

\begin{abstract}
Forest loss and degradation is occurring at high rates but humankind is experiencing historical momentum that favors forest restoration. Approaches to restoration may follow various paradigms depending on stakeholder objectives, regional climate, or the degree of site degradation. The vast amount of land requiring restoration implies the need for spatial prioritization of restoration efforts according to cost-benefit analyses that include ecological risks. To design resistant and resilient ecosystems that can adapt to emerging circumstances, an adaptive management approach is needed. Global change, in particular, imparts a high degree of uncertainty about the future ecological and societal conditions of forest ecosystems to be restored, as well as their desired goods and services. We must also reconsider the suite of species incorporated into restoration with the aim of
\end{abstract}

Douglass F. Jacobs

djacobs@purdue.edu

1 Department of Forestry and Natural Resources, Purdue University, West Lafayette, IN 47907, USA

2 Departamento de Sistemas y Recursos Naturales, Universidad Politécnica de Madrid, Madrid, Spain

3 Centre d'Ecologie Fonctionnelle et Evolutive (UMR 5175-Campus du CNRS), 1919, Route de Mende, 34293 Montpellier, France

4 Missouri Botanical Garden, 4344 Shaw Blvd., St. Louis, MO 63110, USA

5 Institute of Forest Ecosystems, Johann Heinrich von Thünen-Institute, Eberswalde, Germany

6 NERC Centre for Ecology and Hydrology, Wallingford OX10 8BB, UK

7 Faculty of Forest Sciences and Natural Resources, Institute of Forests and Society, Universidad Austral de Chile, Valdivia, Chile

8 Department of Renewable Resources, University of Alberta, Edmonton, Canada

9 Forest and Landscape College, University of Copenhagen, Copenhagen, Denmark

10 Sun Yat-sen University, Guangzhou, China

11 Departamento de Ciencias de la Vida, Universidad de Alcalá, Alcalá de Henares, Madrid, Spain

12 World Agroforestry Centre, Headquarters, United Nations Avenue, Gigiri, Nairobi 00100, Kenya 
moving toward more stress resistant and competitive combinations in the longer term. Non-native species may serve an important role under some circumstances, e.g., to facilitate reintroduction of native species. Propagation and field establishment techniques must promote survival through seedling stress resistance and site preparation. An improved ability to generalize among plant functional groups in ecological niche adaptations will help to overcome site-limiting factors. The magnitude and velocity of ongoing global change necessitates rapid responses in genetics that cannot be naturally induced at valid temporal and spatial scales. The capacity for new concepts and technologies to be adopted by managers and accepted by society will depend on effective technology transfer and a community-based approach to forest restoration. The many benefits human society gains from forests requires that forest restoration considers multiple objectives and approaches to minimize trade-offs in achieving these objectives.

Keywords Adaptive management $\cdot$ Ecological resilience $\cdot$ Ecosystem services $\cdot$ Global change $\cdot$ Native species $\cdot$ Reference ecosystems

\section{Challenges of forest restoration and purpose of the congress}

Forest restoration has become more important than ever during the early twenty-first century. The last Forest Resources Assessment (FAO 2015) reported a global net forest loss of $3.3 \times 10^{6}$ ha year $^{-1}$ from 2010 to 2015 , despite substantial reductions in deforestation rates compared to the early 1990s. International and local policy initiatives are thus pushing for an unprecedented amount of restoration as means to protect biodiversity and food security. Numerous global, regional, and national targets have been set for largescale forest landscape restoration. Most notable among these are the commitments to the 2011 Bonn Challenge (www.bonnchallenge.org) to restore 150 million ha of degraded and deforested land worldwide by 2020, the Forest Declaration to restore 350 million ha of forests by 2030 as a result of the 2014 New York Climate Summit, and the recent Initiative $20 \times 20$ launched at the COP 20 in Lima, Peru to restore 20 million ha of forests by 2020 in some Latin American and Caribbean countries. The 2020 Targets of the Convention on Biological Diversity (www.cbd.int/sp/targets/) call for the restoration of ecosystems that provide essential services (Target 14), and enhancement of the contribution of biodiversity to carbon stocks through restoration of at least $15 \%$ of degraded ecosystems (Target 15). The UN REDD + program (www.un-redd.org/) is attempting inter alia to encourage restoration of forests by creating a market value for the carbon stored therein.

Restoration ambition is high with regards to achieving the goals of such programs, but many unknowns remain. The science and practice of restoration are still young, and our ability to recover biodiversity and ecosystem functions fully is currently limited (Ballantine and Schneider 2009; Bullock et al. 2011; Kovalenko et al. 2013). Restoration challenges vary in severity across regions and ecotypes (Whisenant 1999; SER 2004). At present, even with best practices applied, and even in extra-tropical wetlands, where large numbers of restoration projects have taken place over the last 30 years, we are only achieving ca. $70 \%$ of what we aim for, in terms of both biodiversity maintenance and ecosystem service procurement (Moreno-Mateos et al. 2012). We should be able to do much better in the next 20 years with greater investment in science and technology, 
although a need remains to make these practices economically competitive in the shortterm (Stern 2006).

In recent decades, an evolution has occurred in both the characteristics of degraded areas in need of restoration and the fundamental objectives of restoration programs (Higgs et al. 2014). Many areas that had been converted to agriculture have since been afforested while intensive management practices, such as surface mining and road construction, yield extremely harsh environments that make restoration difficult. Increasing public concern about ecological sustainability requires that restoration counteract environmental impacts, while simultaneously restoring forest species, rehabilitating structure and function, and enhancing carbon sequestration capacity and other ecosystem services of the land (SER 2004; Martin et al. 2013; IUCN and WRI 2014; Cunningham et al. 2015).

These tasks must now be accomplished under the dynamic nature of climatic change that implies increased exposure to drought and generally more extreme weather in many regions of the world (IPCC 2012). To meet these demands, new advances are needed, especially to account for a greater range of species and genotypes that reflect an increase in climatic variability for forest restoration activities. Selection of species and genetic material as well as nursery cultural practices must focus on overcoming planting stress on harsh restoration sites by enhancing the ability of seedlings to withstand frost, drought, nutrient deficits, vegetative competition, and browsing or grazing. As global estimates of land area requiring restoration now exceed 2 billion ha (Minnemayer et al. 2011), there is also a need to focus on prioritization and cost-effectiveness of restoration techniques. Concurrently, the science of forest restoration is evolving rapidly with advances in knowledge and in decision systems to meet societal demands, along with current and predicted ecological alterations derived from global change.

In September 2011, we held the 1st IUFRO Restoring Forests Congress in Madrid, Spain to address recent advances in forest restoration techniques and theory. Selected papers from this symposium were published in New Forests (Vol. 33, Issues 5-6). While most of the challenges and emerging issues that were emphasized during the 1st Restoring Forests Congress (Oliet and Jacobs 2012) are still under debate, some changes in strategies, priorities and foci deserve new attention and reflection. To continue to communicate and advance upon these themes, we held the $2^{\text {nd }}$ IUFRO Restoring Forests Congress on 14-16 October 2014 in Lafayette, Indiana USA (Purdue University). The symposium was organized and supported by Purdue University, the USDA Forest Service, and the Hardwood Tree Improvement and Regeneration Center, as well as IUFRO Divisions 1.01.00 (Temperate and Boreal Silviculture), 1.06.00 (Restoration of Degraded Sites), 2.01.00 (Physiology), and 3.02.00 (Stand Establishment). We sought to re-define the scope of forest restoration and narrow our vision of restoration success in relation to a realistic, achievable end result while maintaining the ultimate goal of supporting the sustainable development of society clearly in mind. We prioritized the inclusion of an applied research approach to make progress of science and development useful to restoration practitioners as well as policy-makers. A total of 114 scientists, representing 16 countries and 15 US States, attended the Congress, which included 8 invited seminars, 45 offered oral presentations, and 28 poster presentations. Field tours highlighted the ongoing forest restoration research of the Hardwood Tree Improvement and Regeneration Center (www.htirc.org) at Purdue University, featuring especially the role of genetics in ecological restoration. The Congress framework was derived in accordance with the traditional configuration of a restoration project, from the definition of objectives and strategies to specific techniques to improve restoration success. This structure emphasizes the technical dimensions of restoration, which has constituted a major theme of the Restoring Forests Congress series thus far, but 
also integrates an evolving socio-ecological context that affects restoration techniques in a cyclical feedback process. The overall theme of the 2nd Congress was Restoring ForestsWhat Constitutes Success in the twenty-first Century? The Congress was arranged according to the following centralized topics, and within each topic, several key issues emerged:

\section{Forest restoration: objectives, strategies, and needs}

Theoretical issues related to forest restoration are dynamic and still evolving, as forest restoration is a relatively young science. When designing a restoration project, properly defining objectives is one of the most critical tasks to ensure long-term sustainability. A key issue is conducting a community-based approach to forest restoration (IUCN 2014; Derak and Cortina 2014). Additionally, defining and refining objectives within the context of a rapidly changing world must be accomplished using a flexible framework. The concept of adaptive management (i.e., simultaneous learning and resource management in the face of uncertainty; Williams 2011) has reached forest restoration, with multiple implications that emerged during the Congress and this Special Issue. One of these is the definition and utility of a "reference ecosystem", which must be revisited given profound changes in the theory of ecological restoration (Balaguer et al. 2014; Higgs et al. 2014). Linked to this, global change involves a high uncertainty regarding future ecological conditions of ecosystems to be restored, not only in relation to the changing climate itself but also with the interacting effects of climate on the introduction of invasive species or anthropogenic processes that affect land-use changes such as forest fragmentation. The risks and uncertainties of the effects of global change upon forest ecosystems require designing resilient ecosystems that will have a greater adaptive capacity to these new scenarios. For instance, we must reconsider the suite of species incorporated into restoration with the aim of moving in the longer term toward more stress resistant and competitive forest communities. Non-native species could play an important role in this capacity, particularly in cases where they provide short-term benefits to ecosystem function and promote the potential for longer-term succession to native species in ways that cannot be achieved by relying solely upon native flora (Davis et al. 2011; Ostertag et al. 2015; Fig. 1). However, it must be acknowledged that arguments for using non-natives, disregarding reference ecosystems, and related re-definitions of restoration are controversial and debated vigorously (Murcia et al. 2014; Peltzer et al. 2015).

The vast amount of degraded land implies that the practice of restoration must be done efficiently at all levels and decision phases, from landscapes to interior stands. Spatial prioritization of restoration efforts according to cost-benefit analyses that include ecological risks is crucial (Lammerant et al. 2013). At the landscape level, effective restoration can be accomplished, for example, by creating forest fragments strategically positioned to maximize the fulfillment of ecosystem services, including potential dispersion (Rey-Benayas et al. 2008; Stanturf et al. 2014). As described in the 1st Restoring Forests Congress, developing tools to evaluate and monitor restoration success objectively is essential to accurately track the cost-benefit outputs of restoration efforts, and to learn from past actions using an adaptive approach (Oliet and Jacobs 2012). Recent scientific and technical literature describing the results of former restoration projects (Rey-Benayas et al. 2009; Bonner et al. 2013; Barral et al. 2015) indicates that past experiences in forest restoration must be capitalized upon to accomplish growing restoration needs for the future. This constitutes a living laboratory for developing monitoring tools that help to determine whether current restoration is working (Hallett et al. 2013). 

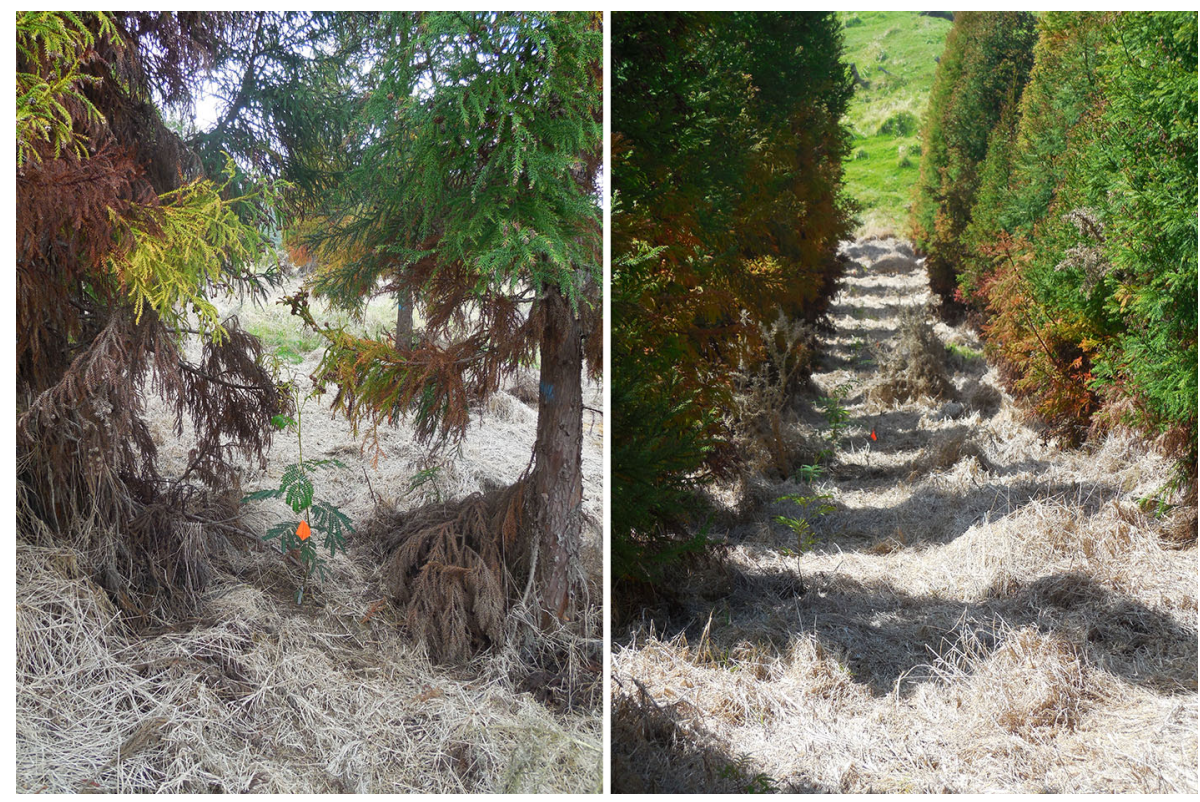

Fig. 1 Using non-native species to accelerate restoration of native Acacia koa A. Gray forests at high elevations in tropical Hawaii, USA. Fast-growing, non-native Cryptomeria japonica (L.f.) D. Don was introduced 12 years ago and has now developed an overstory canopy that reduces frost incidence for planted Acacia koa trees at ground level (Left), and limits the development of an invasive understory (visible in background, Ulex europaeus L., gorse, and Pennisetum clandestinum Hochst. Ex Chiov., kikuyu grass) of non-native herbs and woody species (Right). Photos: Juan A. Oliet

\section{Producing plant materials to resist stress, drivers of seedling field establishment}

The ability of newly regenerating seedlings to overcome stress during the field establishment phase often determines longer-term success of forest restoration (Jacobs et al. 2004; Grossnickle 2012; Villar-Salvador et al. 2012). Production of planting stock adapted to resist environmental stresses on forest restoration sites represents a deviation from past emphasis of nursery stock quality research aimed toward reforestation of forest land with commercial timber species (Oliet and Jacobs 2012). This has prompted a shift from managing for fast growth, mainly by overcoming vegetative competition and animal browsing on cutover sites, to a need to resist stress associated with a more diverse suite of biotic and abiotic site-limiting factors.

Modification of characteristics, such as container size or configuration (Chirino et al. 2008; Morrissey et al. 2010; Pinto et al. 2011), may produce alternative stocktypes more tolerant to drought or browsing. Specific propagation techniques that promote morphological and physiological attributes to enhance cold and drought resistance, for example, have been shown to improve seedling survival on harsh sites (Villar-Salvador et al. 2004; Grossnickle 2012). Furthermore, investigation into the relationships between nitrogen (N) content, $\mathrm{N}$ remobilization, and post-planting success have improved knowledge of adaptations of plant functional groups under varying ecological niches (Uscola et al. 2015). In turn, conceptual models have been developed that emphasize the generally positive 
effect of seedling $\mathrm{N}$ concentration or content on post-planting responses (Villar-Salvador et al. 2012), as well as species-specific techniques to load nutrients in the nursery (Salifu et al. 2009; Oliet et al. 2013). Although early research showed the positive role of reserves of non-structural carbohydrates (NSC) on seedling quality (Marshall 1985), and recent studies have specifically examined the role of NSC in species from different biomes (Landhäusser et al. 2012a; O'Brien et al. 2014), progress in this area has lagged behind that of seedling nutrition. New investigations are needed to help overcome methodological issues and disentangle the role of remobilization versus current uptake of NSC in response to planting stress, e.g., through carbon-labeling approaches (Tomlinson and Anderson 1998). Additionally, new techniques to effectively load seedlings with NSC in the nursery (Landhäusser et al. 2012b) will improve knowledge and management of this important driver of seedling establishment. Finally, the interactive role of belowground microbial communities in site restoration and relationships to nursery or stand-level silvicultural treatments deserves increasing attention because these communities serve as important indicators of healthy, functioning ecosystems (Harris 2009).

\section{Site preparation for restoration: effects on site microclimate and subsequent plant response under harsh conditions}

Recent investigations into ecological interactions at the microsite level have emphasized the importance of small-scale heterogeneity in the distribution of resources and microenvironmental conditions. These studies show positive effects of biotic interactions with facilitation (Perea and Gil 2014; Soliveres et al. 2014), habitat complexity associated with biological legacies (Stanturf et al. 2014), or micro-topography (Questad et al. 2014). This knowledge is essential to design more efficient restoration projects with reduced inputs. Under degraded environments such as with abandoned croplands, surface mining, or highly eroded soils, however, systems lose most of their structural elements and sources of microsite diversity may become limited (Tongway and Hindley 2004; Cortina et al. 2011). In addition, many restoration projects require plant densities and spatial distribution that do not match current structural layout of the biological legacy or micro-topography. Under these circumstances, site preparation techniques and other eco-technologies must be applied to ensure restoration success (Vallejo et al. 2012; Piñeiro et al. 2013), with development of low impact mechanical technologies being of increasing emphasis (Löf et al. 2012). Demand for mine reclamation, for example, is fostering new approaches in site preparation such as geomorphic restoration (Balaguer et al. 2014; Fig. 2) that can be applied in other restoration contexts.

\section{The role of genetics in producing resilient ecosystems}

While forest genetics has served as an important consideration in forest regeneration and restoration since the initiation of science-based action, the role of genetics in an uncertain future is exponentially gaining importance (Bozzano et al. 2014). The magnitude and velocity of ongoing global change will necessitate rapid responses in species selection and population genetics, breeding for insect and disease resistance, and molecular genetics that cannot be naturally induced at valid temporal and spatial scales. Research is needed, for example, to improve selection of better-adapted seed sources for outplanting in different environmental conditions; this is particularly crucial for native species in semi-arid zones that will become increasingly hotter and drier in the future (Weber and Sotelo Montes 2010; Weber et al. 2015). Intense debate has been raised at multiple levels regarding some 


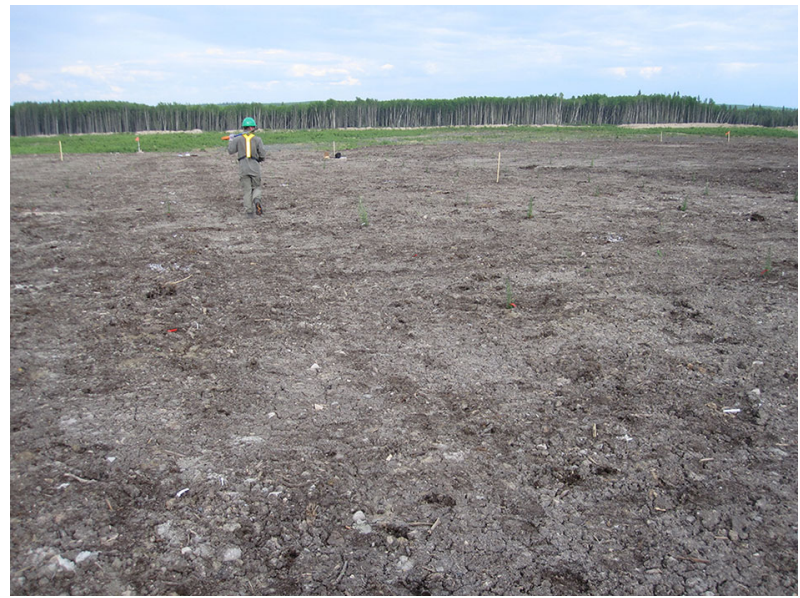

Fig. 2 Mine reclamation site in the Oil Sands Region of Canada, which has undergone landform reconstruction along with placement of a peat-mineral capping material prior to restoration with native boreal forest tree species. Photo: Douglass F. Jacobs

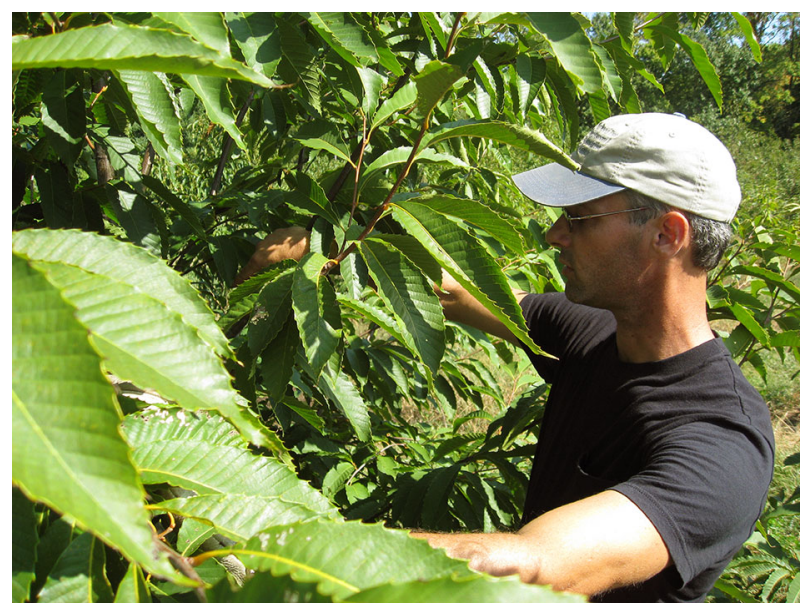

Fig. 3 Test plantation of American chestnut (Castanea dentata (Marsh.) Borkh.) trees that have been hybridized with Chinese chestnut (Castanea mollissima Blume) to produce progeny that are likely to survive the chestnut blight fungus [Cryphonectria parasitica (Murr.) Barr], which was accidentally imported from Asia and destroyed the American chestnut throughout its native range in eastern North America. Photo: Douglass F. Jacobs

applications of genetics to forest restoration, i.e., assisted migration of provenances and species (Dawson et al. 2011; Williams and Dumroese 2013; Stanturf et al. 2014) or the use of classical breeding versus genetic engineering (Merkle et al. 2007; Jacobs et al. 2013; Fig. 3), suggesting that we are in the infancy of navigating these dynamic and critical issues that have long-lasting consequences toward success of forest restoration programs. Progress in effectively incorporating genetic considerations into forest restoration will require improved integration of both social and biological feedback (Aronson et al. 2010; Jacobs et al. 2013). 


\section{Brief presentation of special issue content}

A total of 21 original research or review articles covering a wide range of issues in forest restoration are included in this Special Issue; here, we highlight some of these. In accordance with his inaugural address from the Congress, Stanturf (2015) presents challenges of forest restoration in a global (i.e., landscape) context. He emphasizes the vast amount of degraded area requiring restoration and the need to rely upon an integrative, adaptive approach given the uncertainty of changes in climate as well as social priorities. In practice, several active adaptation strategies may be used to pursue restoration goals; while these vary in functional methodology, they each share similar key objectives. Following Adrian Newton's keynote presentation, Newton and Cantarello (2015) analyze the uncertainty regarding the ability to define and measure forest resilience in a restoration context. One of the challenges they uncover is our reliance upon identification of multiple stable states, which forms a basis for integration of the ecological resilience concept. They suggest a new approach to help guide restoration practices by measuring rates of forest recovery and resistance using meta-analysis and ecological modeling. Nunez-Mir et al. (2015) provide a timely analysis of the 35-year evolution of published scientific literature in forest restoration. As expected, they found a rapid increase in research specific to restoration ecology in the forestry literature. But the scale of its escalation (i.e., a 50-fold increase from 2000 to 2013) is perhaps unprecedented in forest science and a testament to the prominent rise of restoration-related issues affecting the ecology and management of forests. They suggest gaps in current forest science literature in the use of key terms being actively debated in the field of restoration ecology at large, suggesting possible future directions.

In an important evaluation of the capacity of restoration activities to restore ecosystem function over time, Avera et al. (2015) examined soil chemical properties of sites in the US. Appalachian Coal Basin that had been reclaimed/reforested between 5 and 30 years ago in reference to non-mined controls. Many important indicators of ecosystem health did not vary between reclaimed and reference stands, but detectable differences in some other parameters indicate the absence of some critical ecosystem functions. Following on this issue as presented in her keynote address, Ellen Macdonald and co-authors contributed a global review of the challenges involved in restoring ecosystem function following mining disturbance (Macdonald et al. 2015). They advocate use of an integrative operational approach that incorporates key advances in ecological engineering, site preparation, propagation of plant materials, and site silviculture. Friday et al. (2015) envision future restoration of the isolated archipelago of Hawaiian Islands through a case study. Interestingly, they highlight many key themes of the Congress, including the potential utility of non-native species to aid in the initial reclamation of heavily degraded sites, the importance of prioritizing which sites to restore first, and the need to implement cost-effective restoration techniques.

In the paper following her keynote address, Hawkins et al. (2015) synthesize literature regarding the role of ectomycorrhizae in $\mathrm{N}$ nutrition, in special consideration of processes involved on degraded sites characteristic of forest restoration. They discuss disturbance regimes in which restoration may benefit from artificial inoculation of nursery stock or introduction of ectomycorrhizae onto field sites, yet they also highlight the complexity of fully understanding this below-ground community and the challenges of artificially reintroducing a diverse ectomycorrhizal community across heavily disturbed landscapes. In another paper from an invited keynote presentation, Villar-Salvador et al. (2015) traced the 
importance of stored non-structural carbohydrates and $\mathrm{N}$ in determining stress resistance of newly planted forest trees. Using a meta-analysis approach, they found distinctions among plant functional types in storage patterns of carbohydrates and $\mathrm{N}$ within plant tissues as well as their reallocation to support growth following transplant. Differences were tied to varying ecological strategies of plant functional types and they make recommendations for management to encourage plant establishment on harsh sites.

Several case scenario papers were devoted to the effects of site limiting effects on restoration establishment, highlighting for example the impact of predation or shelters on Mediterranean oak regeneration (Castro et al. 2015; Leiva and Vera 2015; Oliet et al. 2015; Rey-Benayas et al. 2015), as well as influences of nursery stock morphology and/or competing vegetation on soil microclimate conditions and growth of Acacia koa A. Gray in Hawaii (Pinto et al. 2015), Nothofagus spp. Blume in the mountain of Chile (Donoso et al. 2015), and Pinus echinata Mill. in the eastern US. (Kabrick et al. 2015). Biochar, a charcoal intended to serve as a soil amendment, has received attention for its increasing use in agronomic systems. Thomas and Gale (2015) present the first meta-analysis on its application to forest restoration systems. Although they uncovered distinctions in responses across ecotypes and species, overall they conclude that biochar has greater potential to promote growth of woody plants in restoration than it does to improve growth of agronomic crops.

Finally, the role of genetics in producing resilient ecosystems under global change was debated during the Congress. Dumroese et al. (2015) conceptualize how functional restoration, assisted migration, and bioengineering may be applied independently or concurrently to help meet restoration goals. They illustrate this using the example of the threatened tree, Fraxinus nigra Marsh., and conclude that the capacity for such a framework to be adopted by managers and accepted by society will depend at least partly on effective technology transfer and an adaptive approach that considers changing societal values. In a more specific analysis of assisted migration, Benito-Garzón and FernándexManjarrés (2015) modeled volume and mortality responses for two important Mediterranean pines, highlighting the fuzzy relationship between these parameters and seed sources or target planting locales. This reiterates the need for additional research (e.g., short-term provenance tests under controlled conditions and field sites) to optimize effectiveness of assisted migration programs.

\section{Key conclusions}

Forest restoration is a relatively new branch of forest science that has advanced rapidly through integration of knowledge from related fields. New challenges have emerged in the twenty-first century of direct relevance to forest management and ecological restoration, many of which are time sensitive yet require careful decision making as they carry longterm implications to ecosystem function and resilience. Several key themes reiterated during the course of the Congress and throughout this Special Issue warrant consideration by scientists and managers involved in forest restoration:

- Forest loss and degradation still occur at high rates but humankind is experiencing an historical momentum that favors forest restoration at the global, regional, and national levels.

- The definition and utility of a reference ecosystem must be revisited given profound changes in the theory of ecological restoration. However, according to many, it still has 
an important role in distinguishing restoration and ecological rehabilitation from activities that do not give priority to historical continuity (SER 2004).

- Global change imparts a high degree of uncertainty regarding the future ecological conditions of forest ecosystems to be restored, in relation to a changing climate as well as interactions with land-use changes, i.e., conversion, fragmentation, and degradation.

- The concept of adaptive management has reached forest restoration, i.e., iteratively defining and refining objectives and practices in a simultaneous process using a flexible framework within the context of a rapidly changing world.

- We must aim to restore, rehabilitate, and in some cases design resistant and resilient forest ecosystems that can adapt to emerging circumstances, i.e., ecosystems with a high adaptive capacity.

- The vast amount of land requiring restoration implies the need for spatial prioritization of restoration efforts according to cost-benefit analysis that includes ecological risks.

- We must reconsider the suite of species incorporated into restoration with the aim of moving toward more stress resistant and competitive combinations in the longer term. While native species should be prioritized whenever possible, non-native species may serve an important role under some circumstances. This remains controversial, however.

- Nursery propagation and seedling quality assessment must shift from a focus on reforestation practices designed to promote fast growth on cutover sites toward promotion of seedling survival through greater stress resistance.

- An improved ability to generalize among plant functional groups in ecological niche adaptations is needed to overcome the diverse suite of biotic and abiotic site-limiting factors characteristic of restoration sites.

- In degraded environments, site preparation is often necessary to restore structural elements and sources of microsite diversity, with low-impact mechanical site preparation being of increasing emphasis on restoration sites.

- The magnitude and velocity of ongoing global change will necessitate rapid responses in genetics that cannot be naturally induced at valid temporal and spatial scales. It is important, therefore, to identify better-adapted species and optimize provenance selection for assisted migration.

- The many benefits that society gains from protected and restored forests, i.e., their ecosystem goods and services, requires forest restoration to consider multiple objectives and approaches to minimize trade-offs in achieving these objectives.

- The capacity for new concepts and technologies to be adopted by managers and accepted by society will depend on effective technology transfer and a communitybased approach to forest restoration.

With the conclusion of the Congress, we renewed our universal commitment to reinforce our role as a multidisciplinary working group that periodically gathers to collectively address forest restoration issues. We agreed that the 3rd IUFRO Restoring Forests would be held during 2017 in Scandinavia.

Acknowledgments We are most grateful to all authors of this Special Issue of the $2^{\text {nd }}$ IUFRO Restoring Forests Congress and particularly appreciate the contributions of articles from invited speakers: Barbara J. Hawkins, S. Ellen Macdonald, Adrian C. Newton, John A. Stanturf, and Pedro Villar-Salvador. We appreciate constructive comments from three reviewers on this manuscript. 


\section{References}

Aronson J, Blignaut JN, Milton SJ, Le Maitre D, Esler KJ, Limouzin A, Fontaine C, de Wit MP, Mugido W, Prinsloo P, Van Der Elst L, Lederer N (2010) Are socioeconomic benefits of restoration adequately quantified? A meta-analysis of recent papers (2000-2008) in restoration ecology and 12 other scientific journals. Restor Ecol 10:143-154

Avera BN, Strahm BD, Burger JA, Zipper CE (2015) Development of ecosystem structure and function on reforested surface-mined lands in the Central Appalachian Coal Basin of the United States. New For. doi:10.1007/s11056-015-9502-8

Balaguer L, Escudero A, Martín-Duque JF, Mola I, Aronson J (2014) The historical reference in restoration ecology: re-defining a cornerstone concept. Biol Conserv 176:12-20

Ballantine K, Schneider R (2009) Fifty-five years of soil development in restored freshwater depressional wetlands. Ecol Appl 19:1467-1480

Barral MP, Rey Benayas JM, Meli P, Maceira NO (2015) Quantifying the impacts of ecological restoration on biodiversity and ecosystem services in agroecosystems: a global meta-analysis. Agric Ecosyst Environ 202:223-231

Benito-Garzón M, Fernández-Manjarrés JF (2015) Testing scenarios for assisted migration of forest trees in Europe. New For. doi:10.1007/s11056-015-9481-9

Bonner MTL, Schmidt S, Shoo LP (2013) A meta-analytical global comparison of aboveground biomass accumulation between tropical secondary forests and monoculture plantations. For Ecol Manage 291:73-86

Bozzano M, Jalonen R, Thomas E, Boshier D, Gallo L, Cavers S, Bordács S, Smith P, Loo J (eds) (2014) Genetic considerations in ecosystem restoration using native tree species State of the World's forest genetic resources - thematic study. FAO and Biodiversity International, Rome

Bullock JJ, Aronson JM, Newton AC, Pywell RF, Rey-Benayas JM (2011) Restoration of ecosystem services and biodiversity. Trends Ecol Evol 26:541-549

Castro J, Leverkus AB, Fuster F (2015) A new device to foster oak forest restoration via seed sowing. New For. doi:10.1007/s11056-015-9478-4

Chirino E, Vilagrosa A, Hernández EI, Matos A, Vallejo VR (2008) Effects of a deep container on morphofunctional characteristics and root colonization in Quercus suber L. seedlings for reforestation in Mediterranean climate. For Ecol Manage 256:779-785

Cortina J, Amat B, Castillo V, Fuentes D, Maestre FT, Padilla FM, Rojo L (2011) The restoration of vegetation cover in the semi-arid Iberian southeast. J Arid Environ 75:1377-1384

Cunningham SC, Mac Nally R, Baker PJ, Cavagnar TR, Beringer J, Thomson JR, Thompson RM (2015) Balancing the environmental benefits of reforestation in agricultural regions. Perspect Plant Ecol Evol Syst 17:301-317

Davis MA et al (2011) Don't judge species on their origins. Nature 474:153-154

Dawson IK, Vinceti B, Weber JC, Neufeldt H, Russell J, Lengkeek AG, Kalinganire A, Kindt R, Lillesø JPB, Roshetko J, Jamnadass R (2011) Climate change and tree genetic resource management: maintaining and enhancing the productivity and value of smallholder tropical agroforestry landscapes. A review. Agrofor Syst 81:67-78

Derak M, Cortina J (2014) Multi-criteria participative evaluation of Pinus halepensis plantations in a semiarid area of southeast Spain. Ecol Indic 43:56-68

Donoso PJ, Soto DP, Fuentes C (2015) Differential growth rates through the seedling and sapling stages of two Nothofagus species underplanted at low-light environments in an Andean high-graded forest. New For. doi:10.1007/s11056-015-9480-X

Dumroese RK, Williams MI, Stanturf JA, Clair JBS (2015) Considerations for restoring temperate forests of tomorrow: forest restoration, assisted migration, and bioengineering. New For. doi:10.1007/s11056015-9504-6

FAO (2015) Global forest resources assessment 2015: how are the world's forests changing? Food and Agriculture Organization of the United Nations. Rome, Italy. http://www.fao.org/3/a-i4793e.pdf

Friday JB, Cordell S, Giardina CP, Inman-Narahari F, Koch N, Leary JJK, Litton CM, Trauernicht C (2015) Future directions for forest restoration in Hawai' $i$. New For. doi:10.1007/s11056-015-9507-3

Grossnickle SC (2012) Why seedlings survive: influence of plant attributes. New For 43:711-738

Hallett LM, Diver S, Eitzel MV, Olson JJ, Ramage BS, Sardinas H, Statman-Weil Z, Suding KN (2013) Do we practice what we preach? Goal setting for ecological restoration. Rest Ecol 21:312-319

Harris J (2009) Soil microbial communities and restoration ecology: facilitators or followers? Science 325:573-574

Hawkins BJ, Jones MD, Kranabetter JM (2015) Ectomycorrhizae and tree seedling nitrogen nutrition in forest restoration. New For. doi:10.1007/s11056-015-9488-2 
Higgs E, Falk DA, Guerrini A, Hall M, Harris J, Hobbs RH, Jackson ST, Rhemtulla JM, Throop W (2014) The changing role of history in restoration ecology. Front Ecol Environ 12:499-506

IPCC (2012) Managing the risks of extreme events and disasters to advance climate change adaptation. A special report of working groups I and II of the intergovernmental panel on climate change. Cambridge University Press, Cambridge, 582

IUCN (2014) Assessing forest landscape restoration opportunities at the national level: a guide to the restoration opportunities assessment methodology (ROAM) Gland. IUCN, Switzerland, p 123

IUCN, WRI (2014) A guide to the restoration opportunities assessment methodology (ROAM): assessing forest landscape restoration opportunities at the national or sub-national level. Working Paper (Roadtest edition). IUCN, Gland, 125

Jacobs DF, Ross-Davis AL, Davis AS (2004) Establishment success of conservation tree plantations in relation to silvicultural practices in Indiana, USA. New For 28:23-36

Jacobs DF, Dalgleish HJ, Nelson CD (2013) A conceptual framework for restoration of threatened plants: the effective model of American chestnut (Castanea dentata) reintroduction. New Phytol 197:378-393

Kabrick JM, Knapp BO, Dey DC, Larsen DR (2015) Effect of initial seedling size, understory competition, and overstory density on the survival and growth of Pinus echinata seedlings underplanted in hardwood forests for restoration. New For. doi:10.1007/s11056-015-9487-3

Kovalenko KE, Ciborowski JJH, Daly C et al (2013) Food web structure in oil sands reclaimed wetlands. Ecol Appl 23:1048-1060

Lammerant J, Peters R, Snethlage M, Delbaere B, Dickie I, Whiteley G (2013) Implementation of 2020 EU biodiversity strategy: priorities for the restoration of ecosystems and their services in the EU. Report to the European Commission. ARCADIS (in cooperation with ECNC and Eftec). http://ec.europa.eu/ environment/nature/biodiversity/comm2006/pdf/2020/RPF.pdf

Landhäusser SM, Pinno BD, Lieffers VJ, Chow PS (2012a) Partitioning of carbon allocation to reserves or growth determines future performance of aspen seedlings. For Ecol Manage 275:43-51

Landhäusser SM, Rodríguez-Álvarez J, Marenholtz EH, Lieffers VJ (2012b) Effect of stock type characteristics and time of planting on field performance of aspen (Populus tremuloides Michx.) seedlings on boreal reclamation sites. New For 43:679-693

Leiva MJ, Vera M (2015) Effect of artificial shelters of dead branches on acorn survival and dispersal in shrub-lacking Mediterranean dehesas. New For. doi:10.1007/s11056-015-9486-4

Löf M, Dey CD, Navarro RM, Jacobs DF (2012) Mechanical site preparation for forest restoration. New For 43:825-848

Macdonald SE, Landhäusser SM, Skousen J, Franklin J, Frouz J, Hall S, Jacobs DF, Quideau S (2015) Forest restoration following surface mining disturbance: challenges and solutions. New For. doi:10.1007/ s11056-015-9506-4

Marshall JD (1985) Carbohydrate status as an index of seedling quality. In: Duryea M (ed) Evaluating seedling quality. Principles, procedures and predictive abilities of major tests. Forest Research Laboratory, Oregon State University, Corvallis

Martin PA, Newton AC, Bullock JM (2013) Carbon pools recover more quickly than plant biodiversity in tropical secondary forests. Proc R Soc B 280:8

Merkle SA, Andrade GM, Nairn CJ, Powell WA, Maynard CA (2007) Restoration of threatened species: a noble cause for transgenic trees. Tree Genet Genomes 3:111-118

Minnemayer S, Laestadius L, Sizer N, Saint-Laurent C, Popapov P (2011) A world of opportunity. World Resource Institute, Washington, DC. http://www.wri.org/sites/default/files/world_of_opportunity_ brochure_2011-09.pdf

Moreno-Mateos D, Power ME, Comín FA, Yockteng R (2012) Structural and functional loss in restored wetland ecosystems. PLoS Biol 10:e1001247

Morrissey RC, Jacobs DF, Davis AS, Rathfon RA (2010) Survival and competitiveness of Quercus rubra regeneration associated with planting stocktype and harvest opening intensity. New For 40:273-287

Murcia C, Aronson J, Kattan GH, Moreno-Mateos D, Dixon K, Simberloff D (2014) A critique of the "novel ecosystem' concept. Trends Ecol Evol 29:548-553

Newton AC, Cantarello E (2015) Restoration of forest resilience: an achievable goal? New For. doi:10.1007/ s11056-015-9489-1

Nunez-Mir GC, Iannone BV, Curtis K, Fei S (2015) Evaluating the evolution of forest restoration research in a changing world: a "big literature" review. New For. doi:10.1007/s11056-015-9503-7

O'Brien MJ, Sebastian Leuzinger CD, Philipson JT, Hector A (2014) Drought survival of tropical tree seedlings enhanced by non-structural carbohydrate levels. Nat Clim Change 4:710-714

Oliet JA, Jacobs DF (2012) Restoring forests: advances in techniques and theory. New For 408:535-541

Oliet JA, Puértolas J, Planelles R, Jacobs DF (2013) Nutrient loading of forest tree seedlings to promote stress resistance and field performance: a Mediterranean perspective. New For 44:649-669 
Oliet JA, Vázquez de Castro A, Puértolas J (2015) Establishing Quercus ilex under Mediterranean dry conditions: sowing recalcitrant acorns versus planting seedlings at different depths and tube shelter light transmissions. New For. doi:10.1007/s11056-015-9495-3

Ostertag R, Warman L, Cordell S, Vitousek PM (2015) Using plant functional traits to restore Hawaiian rainforest. J Appl Ecol 52:805-809

Peltzer DA, Bellingham PJ, Dickie IA, Hulme PE (2015) Commercial forests: native advantage. Science $11: 1176$

Perea R, Gil L (2014) Shrubs facilitating seedling performance in ungulate-dominated systems: biotic versus abiotic mechanisms of plant facilitation. Eur J For Res 133:525-534

Piñeiro J, Maestre FT, Bartolomé L, Valdecantos A (2013) Ecotechnology as a tool for restoring degraded drylands: a meta-analysis of field experiments. Ecol Eng 61:133-144

Pinto JR, Marshall JD, Dumroese RK, Davis AS, Douglas RC (2011) Establishment and growth of container seedlings for reforestation: a function of stocktype and edaphic conditions. For Ecol Manage 261:1876-1884

Pinto JR, Davis AS, Leary JJK, Aghai MM (2015) Stocktype and grass suppression accelerate the restoration trajectory of Acacia koa in Hawaiian montane ecosystems. New For. doi:10.1007/s11056015-9492-6

Questad EJ, Kellner JR, Kinney K, Cordell S, Asner GP, Thaxton J, Diep J, Uowolo A, Brooks S, InmanNarahari N, Evans SA, Tucker B (2014) Mapping habitat suitability for at-risk plant species and its implications for restoration and reintroduction. Ecol Appl 24:385-395

Rey Benayas JM, Bullock JM, Newton AC (2008) Creating woodland islets: a new approach to reconcile ecological restoration, conservation, and agricultural land use. Front Ecol Environ 6:329-336

Rey Benayas JM, Newton A, Diaz A, Bullock JM (2009) Enhancement of biodiversity and ecosystem services by ecological restoration: a meta-analysis. Science 325:1121-1124

Rey Benayas JM, Martínez-Baroja L, Pérez-Camacho L, Villar-Salvador P, Holl KD (2015) Predation and aridity slow down the spread of 21-year-old planted woodland islets in restored Mediterranean farmland. New For. doi:10.1007/s11056-015-9492-6

Salifu KF, Jacobs DF, Birge ZKD (2009) Nursery nitrogen loading improves field performance of bareroot oak seedlings planted on abandoned mine lands. Rest Ecol 17:339-349

Society for Ecological Restoration (SER) (2004) The SER international primer on ecological restoration. http://www.ser.org/resources/resources-detail-view/ser-international-primer-on-ecological-restoration

Soliveres S, Smit C, Maestre FT (2014) Moving forward on facilitation research: response to changing environments and effects on the diversity, functioning and evolution of plant communities. Biol Rev 90:297-313

Stanturf JA (2015) Future landscapes: opportunities and challenges. New For. doi:10.1007/s11056-0159500-X

Stanturf JA, Palik BJ, Dumroese RK (2014) Contemporary forest restoration: a review emphasizing function. For Ecol Manage 331:292-323

Stern NC (2006) Stern review: the economics of climate change. Executive summary. http://web.archive. org/web/20090126151412/http://hm-treasury.gov.uk/d/Executive_Summary.pdf

Thomas SC, Gale N (2015) Biochar and forest restoration: a review and meta-analysis of tree growth responses. New For. doi:10.1007/s11056-015-9491-7

Tomlinson PT, Anderson PD (1998) Ontogeny affects response of northern red oak seedlings to elevated $\mathrm{CO}_{2}$ and water stress. II. Recent photosynthate distribution and growth. New Phytol 140:493-504

Tongway DJ, Hindley N (2004) Landscape function analysis: procedures for monitoring and assessing landscapes with special reference to minesites and rangelands. Sustainable Ecosystems, Commonwealth Scientific and Industrial Research Organisation, Canberra

Uscola M, Villar-Salvador P, Gross P, Maillard P (2015) Fast growth involves high dependence on stored resources in seedlings of Mediterranean evergreen trees. Ann Bot 115:1001-1013

Vallejo RV, Smanis A, Chirino E, Fuentes D, Valdecantos A, Vilagrosa A (2012) Perspectives in dryland restoration: approaches for climate change adaptation. New For 43:561-579

Villar-Salvador P, Planelles R, Oliet J, Penuelas-Rubira JL, Jacobs DF, Gonzalez M (2004) Drought tolerance and transplanting performance of holm oak (Quercus ilex) seedlings after drought hardening in the nursery. Tree Physiol 24:1147-1155

Villar-Salvador P, Puértolas J, Cuesta B, Peñuelas JL, Uscola M, Heredia-Guerrero N, Rey Benayas JM (2012) Increase in size and nitrogen concentration enhances seedling survival in Mediterranean plantations. Insights from an ecophysiological conceptual model of plant survival. New For 43:755-770

Villar-Salvador P, Uscola M, Jacobs DF (2015) The role of stored carbohydrates and nitrogen in the growth and stress tolerance of planted forest trees. New For. doi:10.1007/s11056-015-9499-Z 
Weber JC, Sotelo Montes C (2010) Correlations and clines in tree growth and wood density of Balanites aegyptiaca (L.) Delile provenances in Niger. New For 39:39-49

Weber JC, Sotelo Montes C, Kalinganire A, Abasse T, Larwanou M (2015) Genetic variation and clines in growth and survival of Prosopis africana from Burkina Faso and Niger: comparing results and conclusions from a nursery test and a long-term field test in Niger. Euphytica 205:809-821

Whisenant SG (1999) Repairing damaged wildlands: a process-oriented, landscape-scale approach. Cambridge University Press, Cambridge

Williams BK (2011) Adaptive management of natural resources-framework and issues. J Environ Manage 92:1346-1353

Williams MI, Dumroese RK (2013) Preparing for climate change: forestry and assisted migration. J For 114:287-297 